удК $32: 929$ Ђилас М.

327(497.1)"1953"

DOI https://doi.org/10.31212/tokovi.2020.3.mil.117-137

Оригинални научни рад

Примљен: 9. 6. 2020.

Прихваћен: 1. 10. 2020.

Aleksandar V. MILETIĆ

Institute for Recent History of Serbia, Belgrade

samiletic82@gmail.com

\title{
The Role of Milovan Đilas at the Asian Socialist Conference in Rangoon, 1953
}

\begin{abstract}
In the early 1950s, in view of its specific foreign policy, Yugoslavia took the first important steps in connecting with non-European countries and building the foundations of a future policy of neutrality. These plans necessitated the engagement of people that were eminent, influential, and, most importantly, trustworthy. This study focuses on the role of Milovan Đilas, as a high-ranking government and party official within the Yugoslav party delegation at the First Meeting of the Asian Socialist Conference in Rangoon (Burma) in January of 1953.

KEY WORDS: Milovan Đilas, Asian Socialist Conference, Burma, Socialism
\end{abstract}

As one of the most important and influential people in the Yugoslav post-war leadership and one of Josip Broz Tito's closest associates Milovan Đilas was often entrusted with confidential tasks, especially those concerning foreign policy. In numerous post-war foreign policy activities, ${ }^{1}$ Đilas showed enough confidence and political prowess to secure him another engagement as a Yugoslav political envoy to the world.

1 On the foreign policy activities of Milovan Đilas in this period, see: Александар В. Милетић, “Спољнополитичка делатност Милована Ђиласа (1944-1953)”, Југословенска дипломатија 1945-1961, зборник радова, ур. Слободан Селинић, (Београд: ИНИС, 2012), 291-312. 
The mission was the first Asian Socialist Conference (ASC), held in Rangoon, Burma, in January of $1953 .^{2}$

The 1948 Cominform Resolution was a milestone in the history of socialist Yugoslavia, creating serious consequences, ${ }^{3}$ especially in the domain of foreign policy. ${ }^{4}$ In such a situation, Yugoslavia had to establish cooperation with the West, receiving substantial economic and military assistance from that side. ${ }^{5}$ Despite this, the Yugoslav side jealously guarded its independence, refusing to side directly with either bloc. ${ }^{6}$ It tied its policy strictly to the UN institutions, thus sending a clear and unequivocal message regarding its political neutrality, ${ }^{7}$ while forming the basis of a new foreign policy doctrine based on the principle of independence of small countries in relation to great powers and their military-political blocs.

The political map began to change abruptly on the other side of the world, primarily on the Asian and later the African continent. The process of decolonization would inevitably lead to the emergence of various ideas for coordinating the independence policies of the new countries in international politics. In parallel with the policies of international state independence, there was an ongoing process of searching for social, political, and economic models of development for these countries that would present an alternative to the models then being offered by the blocs of the two world superpowers - the USSR and the United States. These were the outlines of the new policy of the new postcolonial world, often referred to at that time as the policy of the "third way" or "third power," initially

2 On Yugoslavia and the First Asian Socialist Conference in Rangoon in 1953, see more: Jovan Čavoški, "Ideološki prijatelj iz daleka: Jugoslavija i Azijska socijalistička konferencija", Istorija 20. veka 1/2019, 139-160; Report of the First Asian Socialist Conference, Rangoon 1953, (Rangoon: An Asian Socialist Publication, 1953).

3 For more on this issue, see: Ljubodrag Dimić, Jugoslavija i hladni rat. Ogledi o spoljnoj politici Josipa Broza Tita (1944-1974), (Beograd: Arhipelag, 2014); Darko Bekić, Jugoslavija u hladnom ratu. Odnosi s velikim silama 1949-1955, (Zagreb: Globus, 1988); Velike sile i male države u hladnom ratu 1945-1955. Slučaj Jugoslavije, priredio Lj. Dimić, (Beograd: Filozofski fakultet, Arhiv SCG, INIS, 2008); Jadranka Jovanović, Jugoslavija u Ujedinjenim nacijama 1945-1953, (Beograd: ISI, 1985).

4 Bekić, Jugoslavija u hladnom ratu, 37-48.

5 See: Dragan Bogetić, Jugoslavija i Zapad 1952-1955. Jugoslovensko približavanje NATO-u (Beograd: Službeni list SRJ, 2000).

6 Diplomatski arhiv Ministarstva spoljnih poslova Republike Srbije (Diplomatic Archives of the Ministry of Foreign Affairs of the Republic of Serbia - DAMSPRS), Politička arhiva (PA)-1952, strogo poverljivo, Ostale partije, f. 13, br. 147, Telegram Milovana Đilasa Vladimiru Dedijeru, 29. I 1952.

7 Arhiv Jugoslavije (Archives od Yugoslavia - AJ), fond 507/ IX, СK SKJ, Komisija za međunarodne odnose i veze (KMOV), Belgija, 11/II-19, Razgovor Josipa Broza Tita sa delegacijom belgijskih socijalista, 30. jula 1952. godine, 4-5. 
known as "neutrality" This was later to develop into the policy of "nonalignment" in relation to the two opposing power blocs. ${ }^{8}$

The core of the policy of neutrality originated in South and Southeast Asia, among the first countries to gain independence: India, Indonesia, and Burma. The policy of neutrality, as an Asian phenomenon, gradually spread to the west of the Asian continent (Middle East), and later to the African continent. ${ }^{9}$ Given its specific foreign policy position, Yugoslavia was the only European country that showed sympathy for nonalignment during the initial phase of this policy. ${ }^{10}$ After 1948, Yugoslavia was completely isolated on the international arena, and its newly proclaimed non-bloc policy, naturally, could not get any support in bloc-divided Europe. ${ }^{11}$ However, the nature of its entire cooperation with the West was technical and pragmatic, not ideological. ${ }^{12}$ According recent research, the first clear signs of Yugoslav interest in the situation in Asia regarding neutrality, appeared as early as in the early $1950 \mathrm{~s}^{13}$

\section{"Đilas Channels" in Relationships with the Western European Socialist Left}

One of Yugoslavia's important connections with the West and the rest of the world during this period was the political left, i.e. parties and movements of a socialist, social-democratic, and even communist (non-Stalinist) orientation. ${ }^{14}$ One of the key people in charge of establishing ties

8 Čavoški, “Ideološki prijatelj iz daleka”, 139. See also: Ranko Petković, Teorijski pojmovi nesvrstanosti, (Beograd: Rad, 1974).

9 More about the origin and development of the policy of non-alignment: Dragan Bogetić, Nesvrstanost kroz istoriju. Od ideje do pokreta, (Beograd: Zavod za užbenike, 2019).

10 On the Yugoslav commitment to the policy of neutrality, later non-alignment, see: Dragan Bogetić, Koreni jugoslovenskog opredeljenja za nesvrstanost, (Beograd: ISI, 1990); Dragan Bogetić, Nova strategija jugoslovenske spoljne politike 1956-1961, (Beograd: ISI, 2006).

11 See: Bekić, Jugoslavija u hladnom ratu, 23-36.

12 See: Ibid., 37-113.

13 Čavoški, "Ideološki prijatelj iz daleka”,140-143; Bogetić, Nesvrstanost kroz istoriju, $21-24$.

14 On the Western European socialist left in this period, see: Stephen Padgett, William E. Paterson, A History of Social Democracy in Postwar Europe, (New York: Longman, 1991); David Childs, The Two Red Flags. European Social Democracy and Soviet Communism since 1945, (London - New York: Routledge, 2002); Peter Van Kemseke, Towards an Era of Development. The Globalization of Socialism and Christian Democracy 1945-1965, (Leuven: Leuven University Press, 2006); Donald Sassoon, One Hundred Years of Socialism. The West European Left in the Twentieth Century, (London - New 
and developing cooperation with the world left was Milovan Đilas. Since 1950, this cooperation had been implemented through the Foreign Policy Commission (FPC) of the Central Committee of the Communist Party of Yugoslavia (CPY) ${ }^{15}$ and the Yugoslav diplomatic missions around the world. Undoubtedly, Đilas became trusted for this kind of international cooperation because of his high position at the very top levels of the Yugoslav party and state and because of his personal affinities and inclinations toward ideological activities and creativity in that regard. During the first half of the 1950s, the most developed cooperation was achieved with the Labour Party of Great Britain, and also with the Socialist Party of France (SFIO), ${ }^{16}$ the Social Democratic Party of Germany, ${ }^{17}$ the Belgian ${ }^{18}$ and Scandinavian Socialists ${ }^{19}$ and other smaller or larger parties, and with the influential world organization, the Socialist International (SI), established in $1951 .{ }^{20}$ In the early 1950 s, through his active involvement in establishing cooperation with the Western European left, Đilas established many connections, formed acquaintances and even made personal friendships with eminent representatives of Western socialists. ${ }^{21}$

York: I. B. Tauris, 2010); Talbot C. Imlay, The Practice of Socialist Internationalism. European Socialists and International Politics, 1914-1960, (Oxford: Oxford University Press, 2018).

15 Vladimir Dedijer, Veliki buntovnik Milovan Đilas. Prilozi za biografiju, (Beograd: Prosveta, 1991), 372.

16 Seе: Александар В. Милетић, “Милован Ђилас и француски социјалисти 19501954", Токови историје 1/2020, 155-174; See also: AJ, fond 507/IX, СК SКJ, KMOV, Francuska, 30/II-17, Poseta delegacije SFIO Jugoslaviji, od 26. marta do 2. aprila 1952; AJ, fond 507/IX, CK SKJ, KMOV, Francuska, 30/II-25, Zabeleška o razgovoru druga Đilasa sa Žil Mokom, 13. septembra 1952; AJ, fond 507/IX, CK SKJ, KMOV, Francuska, 30/II-32, Zabeleška o razgovoru Milovana Đilasa sa Žan Ruom, 24. juna 1953. godine.

17 See: AJ, fond 507/IX, CK SKJ, KMOV, SR Nemačka, 87/II-16, Beogradski razgovori sa Titovim poverenicima (od poslanika Saveznog parlamenta Arna Beriša), 7. VII 1951; AJ, fond 507/IX, CK SKJ, KMOV, SR Nemačka, 87/IX-64, Zabeleška o razgovoru Đilasa sa nemačkim novinarem dr G. Šesnijem, 10. X 1953.

18 See: AJ, fond 507/IX, CK SKJ, KMOV, Belgija, 11/II-12, Zabeleška o razgovoru Milovana Đilasa sa Žozefom Brakoom, članom Politbiroa SPB, 29. X 1951; AJ, fond 507/ IX, CK SKJ, KMOV, Belgija, 11/II-19, Pismo predsednika SPB Maksa Bizea sekretaru Politbiroa СК KРJ Milovanu Đilasu, 14. mart 1952.

19 See: Aleksandar V. Miletić, “'Unrelized Nordic Dream'. Milovan Đilas and the Scandinavian Socialists", Токови историје 3/2015, 89-104.

20 Seе: Александар В. Милетић, Преломна времена. Милован Ђилас и западноевропска социјалистичка и социјалдемократска левица 1950-1954, (Београд: ИНИС, 2019), 57-84. For more on the founding of the Socialist International, see: Imlay, The Practice of Socialist Internationalism, 307-417.

21 Seе: Милетић, Преломна времена, 84-224. 
During the implementation of these activities, as a high-ranking Yugoslav official and representative, Đilas made a substantial and very significant contribution. His work is reflected in laying solid foundations and strengthening reliable channels and ties that enabled Yugoslav foreign policy, especially its unofficial part, to function smoothly and without major problems. Thus, a specific political "penetration" into the West was enabled and facilitated. These "Đilas channels" were used not only to strengthen friendly ties with the left and exchange mutual experiences on building socialism, but also as a means for secret and strictly confidential affairs that implied negotiations on the issue of Yugoslavia's armaments or attempts at unofficial, financial influence through certain individuals and their organizations from the circles of the Western left on the political life of certain Western countries. On the other hand, Đilas' sense of ideological issues, controversy, and even original proposals for political solutions, with a certain dose of personal charm and charisma, undoubtedly left a certain positive impression on many political leaders or intellectuals from Western socialist circles. First of all, we should mention the famous and influential British Labour MP Aneurin Bevan, with whom Đilas built very close and friendly relations. Then, there is cooperation with Morgan Phillips, the general secretary of the British Labour Party, as well as Đilas' acquaintance with Clement Attlee, the leader of the British Labour Party and Britain's post-war prime minister. ${ }^{22}$ Accordingly, the Western European socialist left undoubtedly was an important factor in establishing cooperation with the West during this period. The role of Đilas was very visible and noteworthy. The "Đilas channels" were more than useful and usable in the practice of expanding and consolidating Yugoslavia's influence in the world's socialist movement. In that sense, the world organization of socialist parties, such as the SI - of which the Yugoslav party was not a member - was especially important. ${ }^{23}$

However, the socialist parties in the West were not the only socialist parties in the world with which Yugoslavia had established cooperation at the time. New horizons of Yugoslav foreign policy were emerging

22 See: AJ, fond 507/IX, СК SKJ, KMOV, Velika Britanija, 133/II-1, Sastanak članova Izvršnog odbora NF Jugoslavije sa delegacijom Laburističke stranke Velike Britanije, održan 8. i 9. septembra u Beogradu; AJ, fond 507/IX, CK SKJ, KMOV, Velika Britanija, 133/II-13, Pismo Anojrina Bevana Milovanu Đilasu, 2. jul 1951; AJ, fond 507/IX, CK SKJ, KMOV, Velika Britanija, 133/II-4, Pismo Morgana Filipsa Milovanu Đilasu, 29. decembar 1950; AJ, fond 507/IX, CK SKJ, KMOV, Velika Britanija, 133/II-4, Pismo Milovana Đilasa Morganu Filipsu.

23 Seе: Милетић, Преломна времена, 65-71. 
in the areas of the former colonies, primarily those in Asia, so the socialists there, as well as those in the West, emerged as natural perspective partners for cooperation. ${ }^{24}$ In contrast to the West, Yugoslavia's policy of nonalignment played a special role and this was an additional incentive for the Yugoslav side to intensify that cooperation.

\section{Milovan Đilas and Preparations of the Yugoslav Delegation}

Besides the Western left, which was the focus of cooperation in the first half of the 1950s, the FPC maintained contacts with representatives of other, non-European socialists, especially those from Asia. ${ }^{25}$ As someone who presided over the FPC and who was practically and formally the main person in charge of establishing cooperation with parties and movements in the world, Đilas had meetings not only with representatives of various Asian socialist delegations, but also with representatives of other political, economic, and even military delegations. ${ }^{26}$

Plans to establish an organization such as the ASC began in the late 1940s. The socialists of Burma, India, and Indonesia took a central position in the plan development. The basic political tendencies led to the affirmation and expansion of the idea of independence of Asian peoples and countries ${ }^{27}$ and to the establishment of the policy of neutrality and building their own path to socialism. This fact was especially evident at the Preparatory Meeting of the ASC in March of $1952 .{ }^{28}$ It was decided at the meeting that the First Conference, which was supposed to be held in Rangoon (Burma), was to be attended by the delegates of nine countries and observers of "fraternal delegations." These delegations would consist of representatives of the SI, the International Union of Socialist Youth, and the Communist Party of Yugoslavia. For the CPY, this invitation undoubt-

24 Милетић, “Спољнополитичка делатност Милована Ђиласа”, 311.

25 Čavoški, "Ideološki prijatelj iz daleka", 141-143.

26 See: AJ, fond 507/IX, CK SKJ, KMOV, Burma, 17/VI-3, Zabeleška o razgovoru druga Đilasa sa predstavnicima burmanske privredne delegacije U Ča Njanom i Maung Điem, održanom 30. juna 1952. godine; AJ, fond 507/IX, CK SKJ, KMOV, Burma, 17/ VI-4, Zabeleška o razgovoru druga Đilasa sa burmanskim otpravnikom poslova u Jugoslaviji Tin Maung Guijom, 30. avgusta 1952.

27 Bogetić, Nesvrstanost kroz istoriju, 10.

28 See: AJ, fond 507/IX, CK SKJ, KMOV, Međunarodne organizacije i skupovi, 144/I-2, Report of the Preliminary Meeting for the Asian Socialist Conference held at Rangoon, (25. to 29. March 1952); AJ, fond 142, Socijalistički savez radnog naroda Jugoslavije (SSRNJ), Materijali komisije za međunarodne veze, f. 38, Socijalistička konferencija Azije (Prethodni sastanak održan u Rangunu 25, 26 i 27. marta 1952). 
edly meant great recognition, because the Yugoslavs were the representatives of the only European party that had the privilege to participate independently in the work of the ASC. Undoubtedly, this was a testament to the ideological and political independence of Yugoslavia, both in relation to Soviet communism and Western European socialism. ${ }^{29}$ The representatives of the SI did not look favorably on the mentioned tendencies of the Asian socialists, which in practice could not fully affect the relations between the SI and Yugoslavia. The members of the SI never perceived the Asian socialists equally in the fullest sense. They expressed fear, above all, of the nationalism of Asian parties and a strong policy of complete independence from the great powers in relation to some European countries. ${ }^{30}$

The Burmese Party was in many ways the backbone of the ASC. During this period Yugoslavia had good and intensive relations with Burma. ${ }^{31}$ A Burmese delegation, hosted by Tito at the end of 1951, expressed the desire to strengthen relations between the two countries. ${ }^{32}$ The visit of the Burmese civilian and military delegation in the summer of 1952 was far more significant, when they showed major interest in cooperation with Yugoslavia. ${ }^{33}$ Representatives of the Burmese economic delegation U Kyan Nyein and Maung Gyi also met and talked with Milovan Đilas on that occasion, on June 30, 1952. ${ }^{34}$ The Burmese were very interested in the Yugoslav experience of socialism, as well as in possible cooperation with Yugoslavia at the UN level due to the situation with China, India, and the USSR ${ }^{35}$ Regarding the development of socialism, Đilas emphasized that the Burmese must have their own path to socialism and that this is an important precondition for an policy of independence, both from the USSR and from the United States. ${ }^{36}$

29 Čavoški, "Ideološki prijatelj iz daleka“, 143-147.

30 Ibid.,142.

31 See: Jovan Čavoški, “Arming Nonalignment: Yugoslavia's Relations with Burma and the Cold war in Asia, 1950-1955", CWIHP Working Paper No. 61, (Washington, DC: Woodrow Wilson Center, 2010); Јован Чавошки, "Рука пружена преко света: југословенска подршка Бурми у борби против спољне агресије 1952-1954”, Токови историје 2/2018, 143-176.

32 AJ, fond 507/IX, CK SKJ, KMOV, Burma, 17/VI-1, Izveštaj o poseti dr Sein Banga i Uhla Manga, delegata na VI zasedanju OUN, 27. XII - 30. XII 1951.

33 See: AJ, fond 507/IX, CK SKJ, KMOV, Burma, 17/VI-3, Burmanska vojna i civilna delegacija u Jugoslaviji, jul 1952.

34 AJ, fond 507/IX, CK SKJ, KMOV, Burma, 17/VI-3, Zabeleška o razgovoru druga Đilasa sa predstavnicima burmanske privredne delegacije U Ča Njanom i Maung Điem, održanom 30. juna 1952. godine.

35 Ibid., 1.

36 Ibid., 2 . 
The question of the participation of the Yugoslavs in the First ASC was raised at the meeting between Burmese diplomat Tin Maung Gyi and Milovan Đilas and Aleš Bebler in late August of 1952. The Burmese diplomat informed them about the conference and presented some dilemmas regarding the participation of foreign representatives. Namely, the British Labour Party had suggested its participation as an observer. Gyi, apparently dissatisfied with the British intrusion, told Đilas that the Burmese had not previously planned the participation of foreigners, but if such a possibility were accepted, they would prefer to invite the Yugoslavs in that capacity. Đilas replied that the Yugoslavs would gladly come but that it would be inconvenient if they were the only observer, rather than inviting some more European socialist representatives, for example the Germans or the French. ${ }^{37}$ However, the decision was made in early December of 1952 for the representatives of the CPY (which then had already become the League of Communists of Yugoslavia - LCY) ${ }^{38}$ to send a delegation to Rangoon for a session of the First ASC in January of 1953. On behalf of the LCY, Đilas sent a letter to the ASC Preparatory Committee on December 3, expressing his satisfaction and accepting the invitation for the LCY delegates as a fraternal delegation. ${ }^{39}$ Milovan Đilas, Aleš Bebler, and Anđelko Blažević ${ }^{40}$ were appointed as the LCY delegates. Thus, the LCY was the only independent representative of a European party that was honored to participate at the ASC.

\section{Đilas or Bebler?}

\section{The Suitability of Đilas to Head the Yugoslav Delegation}

With his previously mentioned activities, Đilas undoubtedly gained a certain experience and even routine in relations and assessments of his interlocutors and working with various foreign officials. Also, Đilas' ideological and theoretical activity was no less important at that time, par-

37 AJ, fond 507/IX, СК SКJ, KMOV, Burma, 17/VI-4, Zabeleška o razgovoru druga Đilasa sa burmanskim otpravnikom poslova u Jugoslaviji Tin Maung Guijom, 30. avgusta 1952.

38 In the meantime, at the VI Congress, the Communist Party of Yugoslavia changed its name to the League of Communists of Yugoslavia in early November of 1952. See: Борба комуниста Југославије за социјалистичку демократију: VI конгрес КПЈ(СКJ), (Београд: Култура, 1952).

39 AJ, fond 142, SSRNJ, Materijali komisije za međunarodne veze, f. 38, Pismo Milovana Đilasa sekretaru Pripremnog komiteta Azijske socijalističke konferencije, 3. decembar 1952.

40 Milovan Đilas, Vlast i pobuna, (Beograd: Književne novine, 1991), 252. 
ticularly his theoretically elaborated relations between the socialist states already during the first year of the conflict with the USSR, in mid-1949, emphasizing their international equality, with the affirmation of small states and their right to independence. ${ }^{41}$ That is when the idea of the right of every state to a different and own path to socialism was born. Set as a principle, this idea offered space for cooperation with various representatives of the left in the world. Đilas defended this idea wholeheartedly and enthusiastically, elaborating it in his speeches, texts, polemics and conversations ${ }^{42}$ This, obviously, had an impact on his later choice to participate in the First ASC. Having in mind the stated facts, it could be said that Đilas, at that time the leading party ideologue, seemed to be the most suitable person to head the Yugoslav delegation.

On the other hand, the striking importance of the "second man" of the delegation, Yugoslav diplomat Aleš Bebler, ${ }^{43}$ is obvious. At that time, Bebler was already a man of great diplomatic experience. ${ }^{44} \mathrm{He}$ had already participated in numerous conferences, the first six post-war sessions of the UN General Assembly, as the permanent Yugoslav representative to the UN and a number of other diplomatic activities. In addition, he

41 See: Milovan Đilas, "Lenjin o odnosima među socijalističkim državama”, Komunist, god. III, br. 3, (1949), 1-56; Milovan Đilas, "Lenjin o odnosima među socijalističkim državama”, Borba, 5-11. septembar 1949.

42 Seе: Милован Ђилас, Савремене теме, (Београд: Борба, 1950); “Говор одржан у Специјалном комитету ОУН”, Борба, 2. децембар 1951; “Говор одржан на VI заседању Генералне скупштине ОУН", Борба, 15. децембар 1951; Милован Ђилас, О агресивном притиску влада совјетског блока против Југославије, (Београд: Борба, 1951); Милован Ђилас, “Врти ли се Стаљин у кругу?”, Комунист, год. VI, бр. 6, (1952), 95-121; etc.

43 Aleš Bebler (1907-1981), Yugoslav (Slovenian) diplomat. By profession a lawyer. He was a member of the Communist Party of Yugoslavia since 1929. In the 1930s, he lived in France as a political emigrant, where he received his doctorate in law in Paris. He participated in the Spanish Civil War and the Yugoslav resistance during World War II. After the war, he performed duties in various diplomatic functions. He was Assistant Minister of Foreign Affairs and a member of numerous Yugoslav political and diplomatic delegations, among others, at the Paris Peace Conference in 1946 and the Danube Conference in 1948. He participated in the first six sessions of the UN General Assembly, and in the early 1950s as Yugoslavia's permanent representative to the UN. Ambassador of Yugoslavia to France, India and Indonesia, chairman of the Foreign Affairs Committee of the Federal Assembly, and later a judge of the Constitutional Court and a member of the Federation Council. Decorated with the Order of the People's Hero. He published several books in the field of foreign policy and memoirs, the most famous of which are: Kako sam hitao (How I Rushed), Putovanja po sunčanim zemljama (Travels in Sunny Countries) and Nacionalna suverenost u nuklearnom dobu (National Sovereignty in the Nuclear Age).

44 Seе: Слободан Селинић, Партија и дипломатија у Југославији 1945-1952, (Београд: ИНИС, 2013), 85-86. 
was very highly educated ( $\mathrm{PhD}$ in Paris), had diplomatic skills and knowledge of foreign languages. All this indicates that Bebler had been entrusted with a large portion of the work in this mission, with special emphasis on its technical-operational side. In other words, Bebler could be some kind of "technical" mission operative who could act quickly and efficiently in practice and thus practically lead the mission. In this respect, Bebler's importance is by no means negligible. However, the real and formal head of the mission was undoubtedly Milovan Đilas ${ }^{45}$ because he was not only one of the most prominent political figures at the time, deeply immersed in ideological issues and with almost three years of intense experience of connecting with parties and left movements around the world, but also a man from the very core of the party and state leadership and one of the closest associates of Josip Broz Tito. ${ }^{46} \mathrm{After}$ all, this is confirmed by Bebler in his book of travelogues, where, among other things, he describes the work at the Conference. ${ }^{47}$ In his memoirs, Đilas emphasizes his high status in the narrow leadership circles, which should imply the importance and confidentiality of the visit, and perhaps even giving the delegation a certain dose of representativeness. He attributes importance to Bebler more in an operational than political-ideological sense, "Aleš Bebler and I were chosen for the delegation, he as an experienced diplomat and language expert, and I as a member of the party leadership." 48

\section{Yugoslav Delegation at the Conference}

The first Asian Socialist Conference was held in Rangoon from January 6 to $15,1953,{ }^{49}$ and foreign representatives, in addition to the LCY, also included representatives of the Socialist International..$^{50}$ Among them, the most prominent were Clement Attlee, the head of the British Labour

45 At the sessions of the Conference, Bebler often spoke "on behalf of comrade Đilas," which clearly shows Đilas' supremacy in formulating the official positions of the Yugoslav delegation. On the other hand, it should be noted that Đilas did not speak English, so it is likely that Bebler's help was more than necessary and constant.

46 This is undoubtedly stated in the central document from the First Asian Socialist Conference, the Report from the Conference, where Đilas' name is listed first on the list of the Yugoslav delegation, followed by Bebler and the third member of the delegation, Blažević. (Report of the First Asian Socialist Conference, 112).

47 See: Aleš Bebler, Putovanja po sunčanim zemljama, (Beograd: Kultura, 1954), 126.

48 Đilas, Vlast i pobuna, 252.

49 See: Report of the First Asian Socialist Conference.

50 The Yugoslav delegation left Belgrade on December 25, 1952, and returned from the trip on February 4, 1953. 
Party, and Kay Björk, ${ }^{51}$ the foreign secretary of the Social Democratic Party of Sweden, both influential figures of the Western European left with whom Đilas had already met before. The Conference left a strong impression on the Yugoslav delegates, not only because of the honor paid by the hosts, but also because of the overall atmosphere that further strengthened their beliefs. ${ }^{52}$ The Yugoslav delegation presented its position in Aleš Bebler's introductory speech ${ }^{53}$ at the beginning of the Conference (January 6), which was well received by the Asian socialists, including the Indian representative. On that occasion, Bebler emphasized the international significance of the Yugoslav policy of building socialism and pointed out the importance of the Yugoslav example, of a small country that strives to preserve its independence from the domination of the great powers. ${ }^{54} \mathrm{In}$ that sense, he emphasized Yugoslavia's effort in finding a "common language" among all international factors that are sincere in the fight against the hegemony of the great powers and in respecting the equality of all movements in the world. ${ }^{55}$

The work of the Conference was divided into three groups, or "committees" A, B and C, which covered topics of political, economic, and internal Asian issues, so that each delegation paid attention to those issues that interested it the most. The Yugoslav delegates were deployed in all groups, Đilas in Committee A, Bebler in Committee B and Blažević in Committee $\mathrm{C} .^{56}$ In the official document from the ASC there is no mention of Milovan Đilas being in Committee A, while the names of Bebler and Blažević were registered as being present in the other Committees. ${ }^{57}$ We assume that this was a technical error, because other documents do

51 Čavoški, "Ideološki prijatelj iz daleka", 147.

52 Đilas, Vlast i pobuna, 253.

53 Report of the First Asian Socialist Conference, 20-22.

54 Čavoški, "Ideološki prijatelj iz daleka", 148-149.

55 On this occasion, Bebler said the following, among other things: "It is obvious that both oppression of other countries as well as isolation from other countries are reactionary and harmful for the development of any nation. From this standpoint, we Yugoslavs found easily a common language with all those forces and movements which are in reality striving against aggressive and hegemonistic tendencies and which believe in equal rights of all movements. The attitude of the Soviet Government toward communist movements leads directly to the exploitation and oppression of other countries by Russian imperialism. The fate of Eastern Europe is proof of this. In contrast with such relations, we have to practice a different type of relationship, a relationship of equality as a starting point and example of democratic relationships among socialist nations of the future". Report of the First Asian Socialist Conference, 22.

56 Bebler, Putovanja po sunčanim zemljama, 126.

57 Report of the First Asian Socialist Conference, 113-114. 
show Đilas' active presence in Committee A. ${ }^{58}$ The Yugoslavs participated in debates more or less on all issues, giving suggestions and sharing experiences depending on the specific issues. Bebler noted in his travelogue, published a year later, that Đilas attended the committee as head of the Yugoslav mission: "I never managed to peek into the room where the third committee worked, but I often went to comrade Đilas in the first committee to consult with him, even out of curiosity, because the most important issues were discussed in that committee. All the heads of the delegations were sitting there. That is why this committee was a bit more like a socialist parliament where disagreements were resolved diplomatically, that is, by postponing the discussion, creating subcommittees or working groups that found compromise solutions, which were then adopted by the plenum of the committee..." ${ }^{\prime 9}$ In addition to the official sessions, during the work of the Conference, evening public lectures and discussions were held, so-called "seminars," where the delegations became acquainted with each other's policies and exchanged experiences and opinions. ${ }^{60}$

The notes taken by Đilas during the Conference are of special importance for our topic. From this document, from the session of Committee A, one can clearly see the basic theses of the Yugoslav agenda that they presented to the other delegations. First of all, the Yugoslav side advocated a clear position on the so-called "Cominform Communism" as the ideology behind the Soviet government's "hegemonic and aggressive practice," on the one hand, and "the tendency of the despotic domination of the bureaucracy over the entire social life" on the other, which in turn results in "a suffocation of equality of peoples and human dignity." ${ }^{61}$ According to Đilas, "socialism believes in a democratic administrative mechanism, as

58 See: AJ, fond 142, SSRNJ, Materijali komisije za međunarodne veze, f. 38, Razne zabilješke za istupanje u Komitetu A (rukopis).

59 Bebler described the atmosphere from the meeting of "Committee B" as follows: "The second committee, however, differed from the first. Many delegations and observers, for example representatives of the Socialist International, did not come here. In general, the number of delegates was smaller, so that this committee gained a more working character, and the atmosphere in it was especially cordial. Discussions on issues on which there were disagreements developed directly at the sessions, so sometimes a purely theoretical discussion was entered into, in which the disagreements could be the deepest. However, the atmosphere never deteriorated, because it was this open discussion about all the differences and the presentation of various points of view that brought the delegates even closer. The friendly mood came to the fore here." Bebler, Putovanja po sunčanim zemljama, 126.

60 Ibid., 136.

61 AJ, fond 142, SSRNJ, Materijali komisije za međunarodne veze, f. 38, Razne zabilješke za istupanje u Komitetu A (rukopis). 
opposed to bureaucratic administrative socialism." Also, "socialism believes in international cooperation and peace" based on "equality of peoples and states, the right of peoples to self-determination," and on the developed countries helping those that are underdeveloped..$^{62}$ This document clearly shows that Đilas also noted the "idea" to be "entered" into the official resolution that is based on the view that "socialism in different countries that are pursuing the same goal must go in different directions" and that "therefore equality and cooperation are inevitable." ${ }^{3}$ Đilas emphasized the position of the Yugoslav delegation that "it is in the interest of all peoples, especially Asians, to strive for an independent policy and refuse to participate in any acts of aggression..." ${ }^{64}$ These notes proposed by Đilas at the session of Committee A, as an important document, undoubtedly testify to his direct participation in the debates on the most important issues that were discussed at the Conference.

According to the latest research, the debate in Committee A was the most sensitive and intense, considering that foreign policy issues were on the agenda. The topics discussed were ideology (the "nature" of socialism), "third power," and cooperation with the SI. ${ }^{65}$ What is important for our topic is the fact that Đilas' idea of different paths to socialism was eventually accepted, but not without the disagreement of certain representatives, especially those from India. ${ }^{66}$ As the leader of the Yugoslav delegation, at the Third Plenary Session (January 15), Đilas emphasized his view on the necessity of different paths to socialism, claiming that this was necessary for cooperation among socialists in the world. ${ }^{67}$ However, despite some disagreement (Indian delegate Narayan's claim about the existence of only one path - democratic socialism) ${ }^{68}$ the final text of the resolution accepted Đilas' position on different paths to socialism, and that became

\section{Ibid.}

63 Ibid.

64 Ibid.

65 Čavoški, "Ideološki prijatelj iz daleka”, 151.

66 Report of the First Asian Socialist Conference, 41-42.

67 Ibid., 44.

68 During the Conference, the Yugoslav delegates established very cordial relations with the Indian delegation and its leader Jayaprakash Narayan. This resulted in an invitation to the Yugoslav delegation to visit India after the Conference, which it did. During that visit, Đilas was to meet with a number of Indian politicians, including Nehru, and give a series of lectures on the Yugoslav experience in building socialism. See: Bebler, Putovanja po sunčanim zemljama, 151-168; Đilas, Vlast i pobuna, 255-258. 
one of the key parts of this document, which was undoubtedly important acknowledgment to Yugoslavia and its leadership. ${ }^{69}$

The political views of the Yugoslav delegation particularly irritated the representatives of the British Labour Party, who attended the ASC as members of the delegation of the SI. ${ }^{70}$ Yugoslavia's advocacy of the position on the autonomous development of socialism also made reference to anti-colonial policy, which did not suit the British in any case. Clement Attlee, ${ }^{71}$ the leader of the British Labour Party, obviously paid special attention to Đilas's political influence, so even before the Conference he proposed that the Yugoslavs should be "constructive" in Rangoon and that Đilas should send an official invitation to the Labour Party delegation to attend the upcoming founding Congress of the Socialist Alliance of the Working People of Yugoslavia (in February of 1953).$^{72}$ Thus, Attlee met with Đilas and Bebler on the third day of the Conference, on January 8, 1953. ${ }^{73}$ On that occasion, the Yugoslavs were the guests of the British Embassy at a lunch that was prepared in their honor. According to Đilas' memoirs, the British showed typical British kindness to the Yugoslavs with a good measure of irony regarding the Yugoslav presence at the ASC. ${ }^{74}$ Evidently, the British felt that they had failed at the Conference, which was also noticed by Đilas and Bebler, about which they informed Belgrade. ${ }^{75}$ In essence, the British were dissatisfied because the Yugoslavs had a strong influence on the Conference's decision not to become a member of the SI as a regional organization but to maintain ties with it as an equal partner. ${ }^{76}$ Thus, the British would be in a situation to lose the opportunity to indirectly, through the SI, have an influence on the events

69 Čavoški, "Ideološki prijatelj iz daleka", 151.

70 The British Labour Party was represented by its Leader Clement Attlee and International Secretary Saul Rose. Report of the First Asian Socialist Conference, 112.

71 Clement Attlee (1883-1967), British Labour politician and lawyer. The son of a lower-ranking lawyer, after graduating from school, he was promoted to barrister (higher-ranking lawyer). Before World War II, he was very active in the Labor Party, as its prominent representative and leader of the opposition. During World War II, he served as deputy prime minister (1942-1945), lord president of the council (19431945) and dominions secretary (1942-1945). After the WWII, he was prime minister (1945-1951), and then leader of the opposition (1951-1955), after which he withdrew from active politics. He became a member of the House of Lords in 1955.

72 AJ, fond 507/IX, CK SKJ, KMOV, Velika Britanija, 133/II-35, Poseta vođe Laburističke partije K. Atlija FNRJ, 24. januara 1953.

73 Милетић, “Спољнополитичка делатност Милована Ђиласа”, 312.

74 Đilas, Vlast i pobuna, 255.

75 AJ, fond 836, Kancelarija maršala Jugoslavije (KMJ), I-3-b/157, Telegram Aleša Beblera MIP-u (prenos Đilasovog telegrama), Rangun, 9. januar 1953.

Čavoški, “Ideološki prijatelj iz daleka”, 154. 
on the Asian continent, which was getting increasingly free of the colonial domination of the West. ${ }^{77}$ Finally, it is obvious that the Yugoslavs decisively influenced the ASC to be a completely independent socialist organization, which corresponded to Yugoslavia's policy of neutrality. ${ }^{78}$ Đilas' role as delegation leader is obvious in all this, as can be seen from the reports that he sent to Belgrade. ${ }^{79}$

In addition, Đilas openly proposed very sensitive notions to the delegates. Thus, according to British documents presented by Jovan Čavoški, Đilas suggested that not only Burmese officials but also directly British diplomats support the Asian anti-colonial movements, especially Ho Chi Minh in Vietnam, because they are "authentic revolutionaries like the Yugoslav ones." ${ }^{\prime 0}$ According to Čavoški, these attitudes put forth by Đilas influenced the establishment of the Anti-Colonial Bureau of the Asian Socialist Conference in May of the following year. ${ }^{81}$ The Yugoslav delegation's entire policy and its relations with the anti-colonial movements provoked the unconcealed antipathy of the British, especially their representatives at the Conference and their attending diplomats. ${ }^{82}$

There is no doubt that the political positions of the Yugoslavs aroused suspicions of this kind as well. Thus, in one of his seminar lectures, Đilas presented the basic views of the Yugoslav delegation, ${ }^{83}$ which in principle obviously bothered the representatives of the Western socialists the most. On that occasion, Đilas clearly emphasized: "Two moments are important in this policy: the active fight against aggressive and hegemonic elements and the inseparable fight for the preservation of independence and equality in relations with other countries." ${ }^{\prime 4}$ In addition, Đilas also emphasized the following: "By establishing relations of cooperation with socialist and other democratic movements, the Yugoslav communists not only do not think that they are imposing their

$77 \quad$ Ibid., 152.

78 AJ, fond 836, KMJ, I-3-b/157, Telegram Aleša Beblera MIP-u (prenos Đilasovog telegrama), Rangun, 9. januar 1953.

79 See: AJ, fond 836, KMJ, I-3-b/157, Telegram Aleša Beblera MIP-u (prenos Đilasovog telegrama), Rangun, 9. januar 1953; AJ, fond 836, KMJ, I-3-b/157, Pismo Đilasa i Beblera Ministarstvu inostranih poslova (Kardelju), 11. januar 1953.

80 Čavoški, "Ideološki prijatelj iz daleka", 150.

81 Ibid.

82 Милетић, Преломна времена, 138-140; Nikola Mijatov, Milovan Đilas i evropski socijalisti 1950-1958, (Beograd: ISI, 2019), 56.

83 See: AJ, fond 142, SSRNJ, Materijali komisije za međunarodne veze, f. 38, Seminarsko predavanje Đilasa na Konferenciji, 1-14.

84 Ibid., 14. 
experiences on anyone, but they also think that they would make a serious mistake if they even recommended it as a universal remedy for all countries and situations." 85

There is no doubt that the influence of the Yugoslav delegation's views on the final formulation of the Conference's declarations was very substantial. ${ }^{86}$ This is confirmed by the statements of the Burmese diplomatic representatives in Yugoslavia in the time immediately after the end of the ASC. ${ }^{87}$ In that sense, the Yugoslavs also had very positive impressions about the results of the ASC. ${ }^{88} \mathrm{~A}$ visit to Asia would inspire Đilas to publish an extensive essay "The Eastern Sky" in the Nova misao monthly ${ }^{89}$ after returning from a trip in the middle of 1953.

The participation of the Yugoslav delegation at the First ASC, in January 1953, undoubtedly left a mark not only on the work of this organization, but also on the further activities of Yugoslavia's foreign policy in the Far East. The role of Milovan Đilas, as the head of the delegation, and Aleš Bebler, practically as the "second man," can be considered important in that sense. In addition to cooperating with representatives of the Western European left, Đilas had also been involved in establishing contacts with the Asian Socialists since the early 1950s, and he participated directly in the preparation of the delegation in 1952. The documents, as well as the latest research, show Đilas' influence, both on the work of Committee A at the Conference and on its conclusions, especially on the decision to accept the position on various paths to socialism. The policy of different paths to socialism, without any doubt, directly corresponded to the policy of neutrality, which gave Yugoslavs a special reputation, and in that way Yugoslavia as a country also received important recognition. The success of the Yugoslav delegation at the First ASC was important as a small link in the process of building the policy of neutrality, which later grew into the policy of nonalignment. ${ }^{90}$ This success can be directly at-

85 Ibid.

86 Bekić, Jugoslavija u hladnom ratu, 494.

87 See: AJ, fond 837, Kabinet predsednika Republike (KPR), I-5-b, Zabeleška o razgovoru druga Koče Popovića i burmanskog otpravnika poslova U Tin Maung Đija, 19. januar 1953.

88 Seе: Алеш Беблер, “Рангунска конференција азиских социјалиста”, Наша стварност, год. VII, бр. 3, (1953), 31-43.

89 See: Milovan Đilas, “Istočno nebo", Nova misao, god. I, br. 10, (1953), 519-557.

90 This event was important despite the short duration of relations between the Asian Socialist Conference and the Yugoslav Communists. These relations became more and more moderate over time, especially after the fall of Đilas (in January of 1954), 
tributed to Đilas and his activities in Committee A, which gives his biography one more important piece of information.

\section{Summary}

The conflict with the USSR and the ensuing isolation presented the Yugoslav leadership with the difficult task of looking for a way out and finding various partners for cooperation on the international scene. That is how contacts and cooperation with the Asian Socialist Conference (ASC), a specific regional organization of the Asian Socialist Parties, came about. The ASC had been connected to Yugoslavia mainly through their non-aligned international orientation, but also through the exchange of experiences of social development and building socialism. For these reasons, the CPY received the invitation to participate in the First Asian Socialist Conference in Rangoon (Burma), in January of 1953, and Milovan Đilas and Aleš Bebler were appointed as the Yugoslav delegates. As a specific "team" in the Yugoslav delegation, Đilas and Bebler achieved very good results at the First ASC. However, as the nominal head of the delegation, Đilas undoubtedly influenced the work of the delegation and its political moves in a substantial and decisive way. First, his personal connections with the British Labour Party, who were the main representatives of the Western European Socialists at the ASC, and also his huge personal charisma and political significance as a high-ranking member of the Yugoslav leadership, obviously played a very important role in the work of the delegation. No less important was his theoretical activity at the time, especially his ideas about different paths in building socialism. Thus, the documents point very consistently to Đilas' direct influence on the adopted resolutions of the ASC, especially those regarding the right to different paths to socialism, which focused on anti-colonialism and the policy of independence in relation to the antagonistic blocs.

\section{Sources and Literature}

- $\quad$ Arhiv Jugoslavije: Fond 507/IX, CK SKJ (Komisija za međunarodne odnose i veze); Fond 142, Socijalistički savez radnog naroda Jugoslavije; Fond 836, Kancelarija maršala Jugoslavije; Fond 837, Kabinet predsednika Republike.

- $\quad$ Diplomatski arhiv Ministarstva spoljnih poslova Republike Srbije. Politička arhiva.

so that after the 7th LCY Congress in 1958, they completely died out. See: Čavoški, "Ideološki prijatelj iz daleka", 156-158. 
- $\quad$ Bebler, Aleš. Putovanja po sunčanim zemljama. Beograd: Kultura, 1954.

- Bebler, Aleš. "Rangunska konferencija aziskih socijalista". Naša stvarnost, god. VII, br. 3, (1953), 31-43. (cyrillic)

- $\quad$ Bekić, Darko. Jugoslavija u hladnom ratu. Odnosi sa velikim silama 19491955. Zagreb: Globus, 1988.

- Bogetić, Dragan. Jugoslavija i Zapad 1952-1955. Jugoslovensko približavanje NATO-u. Beograd: Službeni list SRJ, 2000.

- Bogetić, Dragan. Koreni jugoslovenskog opredeljenja za nesvrstanost. Beograd: ISI, 1990.

- $\quad$ Bogetić, Dragan. Nesvrstanost kroz istoriju. O ideje do pokreta. Beograd: Zavod za užbenike, 2019.

- $\quad$ Bogetić, Dragan. Nova strategija jugoslovenske spoljne politike 1956-1961. Beograd: ISI, 2006.

- $\quad$ Childs, David. The Two Red Flags. European Social Democracy and Soviet Communism since 1945. London - New York: Routledge, 2002.

- Čavoški, Jovan. “Arming Nonalignment: Yugoslavia's Relations with Burma and the Cold war in Asia, 1950-1955". CWIHP Working Paper No. 61. Washington, DC: Woodrow Wilson Center, 2010.

- C Čavoški, Jovan. “Ideološki prijatelj iz daleka: Jugoslavija i Azijska socijalistička konferencija“. Istorija 20. veka 1/2019, 139-160. doi: 10.29362/ist20veka.2019.1.cav.139-160

- C Čavoški, Jovan. "Ruka pružena preko sveta: jugoslovenska podrška Burmi u borbi protiv spoljne agresije 1952-1954". Tokovi istorije 2/2018, 143-176. (cyrillic) doi: 10.31212/tokovi.2018.2.cav.143-176

- Dedijer, Vladimir. Veliki buntovnik Milovan Đilas. Prilozi za biografiju. Beograd: Prosveta, 1991.

- $\quad$ Dimić, Ljubodrag. Jugoslavija i Hladni rat. Ogledi o spoljnoj politici Josipa Broza Tita (1944-1974). Beograd: Arhipelag, 2014.

- $\quad$ Đilas, Milovan. O agresivnom pritisku vlada sovjetskog bloka protiv Jugoslavije. Beograd: Borba, 1951. (cyrillic)

- Đilas, Milovan. "Istočno nebo“. Nova misao, god. I, br. 10, (1953), 519-557.

- Đilas, Milovan. "Lenjin o odnosima među socijalističkim državama". Komunist god. III, br. 3, (1949), 1-56.

- $\quad$ Đilas, Milovan. Savremene teme. Beograd: Borba, 1950. (cyrillic)

- $\quad$ Đilas, Milovan. Vlast i pobuna. Beograd: Književne novine, 1991.

- $\quad$ Đilas, Milovan. "Vrti li se Staljin u krugu?" Komunist god. VI, br. 6, (1952), 95121.

- Imlay, Talbot C. The Practice of Socialist Internationalism. European Socialists and International Politics, 1914-1960. Oxford: Oxford University Press, 2018.

- Jovanović, Jadranka. Jugoslavija u Ujedinjenim nacijama 1945-1953. Beograd: ISI, 1985. 
- $\quad$ Kemseke, Peter Van. Towards an Era of Development. The Globalization of Socialism and Christian Democracy 1945-1965. Leuven: Leuven University Press, 2006.

- $\quad$ Laker, Volter. Istorija Evrope 1945-1992. Beograd: CLIO, 1999. (cyrillic)

- $\quad$ Mijatov, Nikola. Milovan Đilas i evropski socijalisti 1950-1958. Beograd: ISI, 2019.

- Miletić, Aleksandar V. "Milovan Đilas i francuski socijalisti 1950-1954". Tokovi istorije 1/2020, 155-174. (cyrillic) doi: 10.31212/tokovi.2020.1.mil. 155-174

- $\quad$ Miletić, Aleksandar V. Prelomna vremena. Milovan Đilas i zapadnoevropska socijalistička i socijaldemokratska levica 1950-1954. Beograd: INIS, 2019. (cyrillic)

- $\quad$ Miletić, Aleksandar V. "Prijem delegacije britanskih laburista kod maršala Tita u okviru njihove prve posete Jugoslaviji, 1950. godine". Tokovi istorije 1/2011, 137-164. (cyrillic)

- $\quad$ Miletić, Aleksandar V. "Spoljnopolitička delatnost Milovana Đilasa 19441953". Jugoslovenska diplomatija 1945-1961, zbornik radova, ur. Slobodan Selinić, 291-312. Beograd: INIS, 2012. (cyrillic)

- Miletić, Aleksandar V. "The Relationships between Yugoslav Communists and Scandinavian Socialists in the Light of Yugoslav Sources (1950-1953)". Acta Histriae 1/2019, 75-87.

- Miletić, Aleksandar V. "Unrelized Nordic Dream'. Milovan Đilas and the Scandinavian Socialists". Tokovi istorije 3/2015, 89-106. doi: 10.31212/ tokovi.2015.3.mil.89-106

- $\quad$ Padgett, Stephen, William E. Paterson. A History of Social Democracy in Postwar Europe. New York: Longman, 1991.

- $\quad$ Petković, Ranko. Teorijski pojmovi nesvrstanosti. Beograd: Rad, 1974.

- $\quad$ Report of the First Asian Socialist Conference, Rangoon 1953. Rangoon: An Asian Socialist Publication, 1953.

- $\quad$ Sassoon, Donald. One Hundred Years of Socialism. The West European Left in the Twentieth Century. London - New York: I. B. Tauris, 2010.

- Selinić, Slobodan. Partija i diplomatija u Jugoslaviji 1945-1952. Beograd: INIS, 2013. (cyrillic)

- Velike sile i male države u hladnom ratu 1945-1955. Slučaj Jugoslavije, ur. Ljubodrag Dimić. Beograd: Filozofski fakultet, Arhiv SCG, INIS, 2008.

- Borba (cyrillic) 


\title{
Резиме
}

Александар В. Милетић

\section{Улога Милована Ђиласа на Азијској социјалистичкој конференцији у Рангуну 1953.}

\begin{abstract}
АПстРАкт: Почетком 50-их година 20. века, услед своје специфичне спољнополитичке позиције, Југославија је направила прве значајније кораке у повезивању са ваневропским државама, градећи темеље будуће политике неутралности. На том плану посебно је било важно ангажовање угледних, утицајних и поузданих људи. У овом раду пажња је усмерена на улогу Милована Ђиласа у оквиру југословенске партијске делегације на првом скупу Азијске социјалистичке конференције, јануара 1953. у Рангуну (Бурма).

КљУчнЕ РЕчи: Милован Ђилас, Азијска социјалистичка конференција, Бурма, социјализам
\end{abstract}

Сукоб са СССР-ом и изолација поставили су југословенском вођству тежак задатак тражења излаза и различитих партнера за сарадњу у свету. Тако је дошло и до контакта и сарадње са Азијском социјалистичком конференцијом (АСК), специфичном регионалном организацијом азијских социјалистичких партија, коју је са Југославијом првенствено спајала ванблоковска међународна оријентација, као и размена искуства друштвеног развоја и изградње социјализма. Из тих разлога је на адресу КПЈ стигао позив за учешће на Првој азијској социјалистичкој конференцији у Рангуну (Бурма), јануара 1953, па су тако за југословенске делегате одређени Милован Ђилас и Алеш Беблер. Као специфичан „тандем“ југословенске делегације, Ђилас и Беблер су постигли веома добре резултате на Првој АСК. Ипак, као номинални шеф делегације, Ђилас је несумњиво суштински и пресудно утицао на њен рад и политичке потезе. Најпре, његове личне везе са британским лабуристима, који су на АСК-у били главни представници западноевропских социјалиста, затим сама репрезентативност његове личности, тј. политички значај који је као део најужег руководства несумњиво поседовао, по свему судећи су 
играли веома важну улогу у раду делегације. Не мању важност имало је и његово тадашње теоретско ангажовање, посебно његове идеје о различитим путевима у изградњи социјализма. Тако документа врло поуздано показују Ђиласов непосредни утицај на усвојене резолуције АСК-а, нарочито оне о праву на различите путеве у социјализам, што је било повезано са антиколонијализмом и политиком независности у односу на супротстављене блокове. 